\title{
Therapeutic Recognition of Nutraceuticals for Health Benefits and Economic Uplifment of Farming Community
}

\author{
Mamta Tiwari $^{{ }^{*}}$ and Vijaya Tiwari ${ }^{2}$ \\ ${ }^{1}$ Director Prioritization Monitoring and Evaluation, Agriculture University, Kota \\ (Rajasthan), India \\ ${ }^{2}$ Biotechnologist, Career Point University Kota (Rajasthan), India \\ *Corresponding author
}

\begin{tabular}{|l|}
\hline Ke y w o r d s \\
Nutraceuticals, \\
Nutritional \\
Transition, \\
Therapeutic, Plant \\
species
\end{tabular}

\section{A B S T R A C T}

Nutritional Transition has brought rapid changes in the structure of the Indian diet. The traditional home cooked meals has been replaced by ready to eat food as a result there is severe breakdown in immunity of the people and elevation in the rate of under-nutrition and obesity. In order to fight with these problems and maintain health standards nutritional capsules has been introduced extracted from herbs, spices and vegetables. Along with this it contribute in economic uplifment of farming community also by taking more and more productions to fulfil the demand. The use of nutritive vegetables, spices and herbal medicines for the treatment of various disease like hepatitis, arthritis, chronic heart diseases, skin disorders, wounds and even cancer have been mentioned in our 'Ayurveda' and proved scientifically by many researchers of modern times. There is an increased awareness among the people for the beneficial effect of nutraceuticals in day to day life. Fruits, spices and vegetables are commonly used by us can serve an important prophylactic and therapeutic role in day to day life. There is an urgent need to explore the beneficial and therapeutic properties of spices, vegetables and medicinal herbs. Therefore, the present study was conducted with the objectives to introduce the capsules to the pateits of different ailments and to analyse the health benefits after intake (consumption) of the nutraceuticals. Nutraceutical capsules were prepared by filling the powder through cleaning, pressing, drying and powdering the vegetables and medicinal herbs. Nutritional cookies were prepared using multigrain flour with Iron, Beta Carotene nutrients extract of vegetables it has been found from the study that garlic and amla have wondering effect on weight \& cholesterol control system. Drumstick's leaves work as blood purifier, rich source of protein and controlling blood sugar level. Giloy is useful in increasing blood platelets and curing the dengue fever, whereas hadjod having a wondering effect a ment of bone fractures, ashwagandha controls hair fall, regulates cholesterol. Therefore, it is recommended that intake of vegetables, spices and medicinal herbs, its powder and its nutraceuticals capsules, cookies can be beneficial for health due to their therapeutic characteristics as immunity developer, blood purifier, cholesterol controller, constipation remover and antialergiqpropertiestion 
Therapeutic Recognition of agriculture produce is an approach that can seeks to maximize agriculture's contribution to nutrition. This strategy stresses the multiple benefits derived from recognizing the nutritional value of food for good health and the social significance by enjoying a variety of foods which ultimately effect agricultural sector through productivity for supporting rural livelihoods and economic upliftment of farmer community. At the same time it motivates the masses for maintaining good health and understanding the value of nutrition rich supplements.

Although all vegetables are beneficial, but interestingly, raw leafy vegetables, have highest levels of vitamins and minerals. Raw vegetables are generally used as salad which helps to maintain the gastrointestinal motility. Vegetables are good for health since they provide intense flavour, vivid colours and crispy rich texture to the dine menu (Xiao et al., 2012). According to Ello-martine et al., 2005 Vegetables are helpful in weight management through controlling hunger. They prevent constipation and enhance gastrointestinal function. Wagensteen et al., 2004 also said that vegetables reduce the chances of metabolic diseases viz., diabetes mellitus and hypercholesterolemia. (Azadbakht et al., 2012) and rich source of vitamins (Vitamin B complex) and minerals (Logendra et al., 2002 and Dahl et al., 2012), they reduce oxidative stress (Esfahani et al., 2011) enhance immunity (Gibson et al., 2012), Consumption of green vegetables reduces the risk of chronic diseases like diabetes, cancer, central nervous system defects, neural tube defects (NTDs) in infants, megaloblastic anaemia and cardiovascular diseases (Adams et al., 2011; Wolfe den et al., 2012; According to Vazquez- Prieto and Miatello, 2010; Esfaham et al., 2011; Imai et al., 2012 and Sun et al., 2012) Carrot beneficial health effects are potent anticancer, artery-protecting immune-modulating infection-fighting, antioxidant properties. Promote reproductive potential, relieve constipation, disease cholesterol have cooling effect, helpful in fevers acidosis constipation, high blood pressure, rheumatism, obesity (Thangam et al., 2013; Stahl and Sies, 2012 and Xiao et al., 2012). Similarly garlic is beneficial as antiparastic, anticancer, antiviral, antibacterial, antiallergic, immunomodulating, antihypertensive, activities, helpful in reducing migraine and blood pressure according to Tan and Vanitha (2004) and Park et al., (2012). Functional foods and nutraceuticals provide an opportunity to improve human health, reduce health care costs, and supports food security and economic development in producing countries. With high nutrient value combined with low cost of production, have good potential to help the malnourished to meet their basic energy needs and nutritional requirements. Some food processing techniques affect the concentrations of nutrients and other bioactive components or their bioavailability. At the same time, advances in food processing technology have provided many techniques for the stabilization of nutrients and other valued substances in food. The use of novel and innovative processing technologies is important for further expansion of consumptions and marketing as these technologies aim to provide safe, high quality foods with desirable nutritional and functional properties.

These problems have forced the scientists and researchers to think about the alternative medicines and their applications (Hashemi and Davoodi, 2012). Herbal medicines have always been a form of therapy for livestock among resources poor marginal farmers (Tan and Vanitha, 2004, Alamgir and Uddin, 2010, Mizaei-Aghsaghali, 2012).

The historical statement of hippocarates "Let 
your food be your medicine and let your medicine be your food" is persisting and gaining more importance. In 1989, Stephen L. Defelice coined the terms nutraceuticals from the words "nutrition" and "Pharmaceuticals" and later defined it to include "foods", dietary supplements and medical foods that have a health-medical benefit including the prevention and/or treatment of disease". While the terms nutraceuticals and functional foods still have no regulatory definition, it is accepted by scientists and food manufacturers to include those foods and their components that provide extra health benefits to humans. Fruits and vegetables are recognized as functional foods according to this definition. In the last decades, it has increasingly been recognized that diets provide humans with more than the necessary nutritional elements including proteins, fats, carbohydrates and the level of minerals and vitamins necessary to combat deficiency symptoms. Functional foods and nutraceuticals provide an opportunity to improve human health, reduce health care costs, and supports food security and economic development in producing countries. With high nutrient value combined with low cost of production, have good potential to help the malnourished to meet their basic energy needs and nutritional requirements. Some food processing techniques affect the concentrations of nutrients and other bioactive components or their bioavailability. At the same time, advances in food processing technology have provided many techniques for the stabilization of nutrients and other valued substances in food. The use of novel and innovative processing technologies is important for further expansion of consumptions and marketing as these technologies aim to provide safe, high quality foods with desirable nutritional and functional properties. Although all vegetables are beneficial, but interestingly, raw leafy vegetables, have highest levels of vitamins and minerals. Raw vegetables are generally used as salad which helps to maintain the gastrointestinal motility. Vegetables are good for health since they provide intense flavour, vivid colours and crispy rich texture to the dine menu (Xiao et al., 2012), they are helpful in weight management through controlling ginger (Ellomartine et al., 2005), they prevent constipation and enhances gastrointestinal function (Wagensteen et al., 2004), they reduce the chances of metabolic diseases viz., diabetes mellitus and hypercholestrolemia (Azadbakht et al., 2012) and rich source of vitamins (Vitamin B complex) and minerals (Logendra et al., 2002 and Dahl et al., 2012), they reduce oxidative stress (Esfahani et al., 2011) and enhance immunity (Gibson et al., 2012), Consumption of green vegetables reduces the risk of chronic diseases like diabetes, cancer, central nervous system defects, neural tube defects (NTDs) in infants, megaloblastic anemia and cardiovascular diseases (Adams et al., 2011; Wolfenden et al., 2012; VazquezPrieto and Miatello, 2010; Esfaham et al., 2011; Imai et al., 2012 and Sun et al., 2012). Carrot's scientific name is Daucus carota and its beneficial health effects are potent anticancer, artery-protecting immunemodulating infection-fighting, antioxidant properties. Promote reproductive potential, relieve constipation, disease cholesterol have cooling effect, helpful in fevers acidosis constipation, high blood pressure, rheumatism, obesity (Thangam et al., 2013; Stahl and Sies, 2012 and Xiao et al., 2012). Similarly garlic's scientific name is Alliumsativum and its beneficial as antiparasitic, anticancer, antiviral, antibacterial, antiallergic, immune modulating, antihypertensive activities, helpful in reducing migraine and blood pressure (Tan and Vanitha, 2004 and Park et al., 2012). There is an increased awareness among the people for the beneficial effect of nutraceuticals in day to day life. Fruits and vegetables are commonly used by us can serve an important prophylactic and therapeutic role 
in day to day life. Therefore, there is an urgent need to explore the beneficial and therapeutic properties of vegetables and medicinal herbs. Therefore the present study was conducted with the objectives to introduce the capsules and nutritional cookies to the patients of different ailments and to analyse the health benefits after intake (consumption) of the nutraceuticals.

\section{Objectives}

To introduce the capsules to the patients of different ailments and nutritional cookies to people of different age group.

To analyse the health benefits after intake (consumption) of the nutraceuticals

\section{Materials and Methods}

Nutraceutical capsules were prepared by filling the powder through cleaning, chopping, pressing, drying and powdering the vegetables and medicinal herbs. For Amla cleaning, removing stones, cutting drying and powdering was the procedure adopted. Similarity fenugreek seed, celery, sonth, ashwagandha, giloy, safed musali were, dried and powdered before filling. Two types of capsules shell were used i.e. colored capsule shells (artificial and attractive in color) and vegetative capsule shells (transparent, colourless, not so very attractive but totally natural).

Nutrient Cookies were prepared by mixing multigrain flour with nutrients powder extracted from vegetables. Nutritional cookies were added with Chocolate powder is small quantity so as to enrich its taste and make it easy and popular for consumption among kids.

Capsules so created were tried on Renal, Hepatic, Cardiac, Hair loss, Diabetics, Joint Ailments, Pulmonary Patients. Five patients of each ailments were tried with nutraceuticals under medical supervisiom and guidance of doctors and dieticians. Similarly Nutritional Cookies were given to Different age groups i.e., 3-6 Yrs, 6-10 yrs, Adolescent girls and Pregnant Ladies. After $3 \&$ half months results were analysed through Frequency and calculation of Percentage of benefits felt and observed by patients were formulated.

Table 1 shows the therapeutic values of all natural vegetables, spices and herbs. Although, table is explanatory self-revealing that consumption of garlic, amla, carrot, drumstick, spinach strengthen immune system and make body strong. Garlic and Amla have wondering effect on weight control system. Drumstick's leafs work as blood purifier, rich source of protein and controlling blood sugar level. Carrot is a rich source of vitamin-A.

It boosts immunity system and improve digestion. India is famous for wonderful treasures of spices and vivid herbs which have its medicinal value. Sonth, fenugreek seed and celery are the part of our kitchen but consumed rarely. Whereas it controls cholesterol and sugar. Celery reduces the risk of diabetes.

Table 2 shows the nutritional composition of Nutraceutical vegetable's powder. It is found that spinach and drumstick contains a greater amount of iron (93.19 mg/100g \&87mg/100gm) Amla contains and Phosphorus $(87.65 \mathrm{mg} / 100 \mathrm{~g})$ that may be the reason why amla is good for alembic person and also helpful in improving immunity. Similarly spinach powder contains iron $(93.19 \mathrm{mg})$ phosphorus $\left(291^{\circ} \mathrm{mg}\right)$ and protein (27.79\%). Spinach increases haemoglobin and good for brain health also. Carrot, Quinnoa, Drumstik and garlic powder are having phosphorus 254.92, 312mg, 378mg and $328 \mathrm{mg}$, respectively. 
Int.J.Curr.Microbiol.App.Sci (2018) 7(8): 4718-4726

Table.1 Health benefits of vegetables, spices and herbs in Nutraceutical capsules

\begin{tabular}{|c|c|c|c|c|}
\hline $\begin{array}{l}\text { S. } \\
\text { No. }\end{array}$ & Capsules & $\begin{array}{l}\text { Common } \\
\text { Name }\end{array}$ & Botanical Name & Therapeutic value \\
\hline \multirow[t]{9}{*}{1.} & Vegetables & & & \\
\hline & Beetroot & Chukandar & Beta vulgaris & $\begin{array}{l}\text { Lowers Blood Pressure, Boost Your Stamina, Fight } \\
\text { Inflammation, Anti-Cancer, Properties, Rich in Valuable } \\
\text { Nutrients and Fiber, Detoxification Support }\end{array}$ \\
\hline & Chenopodium & Bathua & Chenopodium Album & $\begin{array}{l}\text { Cures Constipation, Rich in Vitamin A, Blood Purifier, Loaded } \\
\text { with Crucial minerals, Rich In Vitamin C, Improves Appetite, } \\
\text { Improve Haemoglobin Level, Rich in Amino Acids, Heart Tonic, } \\
\text { Common Medicine for Intestinal Parasites }\end{array}$ \\
\hline & Bitter gourd & Karela & Momordica Carinthia & $\begin{array}{l}\text { Helps in maintaining blood sugar levels, Lowers bad cholesterol } \\
\text { levels, For glowing skin and lustrous hair, Cures hangovers and } \\
\text { cleanses the liver, Helps in weight loss, Boosts your immune } \\
\text { system, Great for your eyes }\end{array}$ \\
\hline & Garlic & Lahsun & Allium sativum & $\begin{array}{l}\text { Reduce cholesterol, relieving arthritis/ inflammatory pain, control } \\
\text { body weight, improves immune system, prevent cancer, hair loss } \\
\text { and anti-fungal infection }\end{array}$ \\
\hline & Amla & Amla & Phyllanthus emblica & $\begin{array}{l}\text { Helps in digestion, good for brain, blood purifier, improves } \\
\text { immunity and makes hair strong and shine }\end{array}$ \\
\hline & Drumstick & Sahjana & Moringa oleifera & $\begin{array}{l}\text { Blood purifier, strengthen bones, lowers blood sugar level, cures } \\
\text { respiratory disorder and good for pregnant women }\end{array}$ \\
\hline & Carrot & Gajar & Daucus carota subsp. sativus & $\begin{array}{l}\text { Rich source of Vitamin-A, boosts immune system, improves } \\
\text { digestion, good source of antioxidants, reduce risk of lung cancer } \\
\text { and improves eye sight }\end{array}$ \\
\hline & Spinach & Palak & Spinacia oleracea & $\begin{array}{l}\text { Rich source of iron, increases hemoglobin, healthy for } \\
\text { cardiovascular system, reduces high blood pressure and good for } \\
\text { brain and memory }\end{array}$ \\
\hline \multirow[t]{5}{*}{2.} & Spices & & & \\
\hline & $\begin{array}{l}\text { Dried ginger } \\
\text { capsule }\end{array}$ & Sonth & Zingiber officinale & $\begin{array}{l}\text { Beneficial for diarrhea treatment, remove constipation and relief } \\
\text { from indigestion and stomachache }\end{array}$ \\
\hline & Fenugreek seed & Methi & Trigonella foenum-graecum & $\begin{array}{l}\text { Balances cholesterol levels, reduces sugar levels, eliminates } \\
\text { inflammation and irritation in skin. beneficial in boils, blisters, } \\
\text { itching, skin irritation and arthritis. }\end{array}$ \\
\hline & Celery & Ajwain & Apium graveolens & $\begin{array}{l}\text { Reduces risk of diabetes and heart diseases, beneficial in mouth- } \\
\text { related diseases, removes stomach disorders, relief from } \\
\text { constipation and helps in digestion }\end{array}$ \\
\hline & $\begin{array}{l}\text { Curry Patta } \\
\text { (Meetha Neem) }\end{array}$ & $\begin{array}{l}\text { Curry Patta } \\
\text { (Meetha } \\
\text { Neem) }\end{array}$ & Muggaya Koenigii & $\begin{array}{l}\text { Cure Diarrhea, Gastrointestinal Protection, Antioxidant } \\
\text { Properties, Anti-diabetic, Properties, Fight Cancer, Lower } \\
\text { Cholesterol Levels, Hair Care, Good for Eyesight, Radio } \\
\text { protective and Chemo-protective, Protect Against Pathogen } \\
\text { Attack, Protect the Liver, Skin Care }\end{array}$ \\
\hline \multirow[t]{7}{*}{3} & Medicinal Herbs & & & \\
\hline & Giloy & Giloy & Mrita Tinospora cordifolia & $\begin{array}{l}\text { Antioxidant properties, improve health, remove toxic substances } \\
\text { from kidneys and liver, increases platelets in blood and also } \\
\text { removes the symptoms of dengue fever. }\end{array}$ \\
\hline & Gangadi & Gangadi & Hadjod & Strengthens bones and aids in the treatment of fracture \\
\hline & Ashwandha & $\begin{array}{l}\text { Ashwa } \\
\text { gndha }\end{array}$ & Withania somnifera & $\begin{array}{l}\text { Good for cardiovascular health, reduce swelling, anti-oxidants } \\
\text { and stress-reducing. Strengthens muscles of heart, regulates } \\
\text { cholesterol, controls hair fall by decreasing the level of cortisol in } \\
\text { the body, effective in controlling bacterial infections in humans. }\end{array}$ \\
\hline & Safed Musali & $\begin{array}{l}\text { Safed } \\
\text { Musali }\end{array}$ & Chlorophytum borivilianum & $\begin{array}{l}\text { Pregnant and lactating women and child can be healthy, very } \\
\text { fruitful even after pregnancy, effective for diabetes, } \\
\text { conjunctivitis, promotes the production of insulin and also keeps } \\
\text { diabetes under control, removes body laxity. }\end{array}$ \\
\hline & Rose & Gulab & Rosa & $\begin{array}{l}\text { Makes Skin Young And Healthy, Beneficial For Skin And Its } \\
\text { Troubles, Good For Women, Makes Immune System Stronger, } \\
\text { Cures Sore Throat, Improves Digestive Powers. Cure For } \\
\text { Constipation And Diarrhea, Maintains Urinary Tract Health, } \\
\text { Natural Stress Buster, Helps to Lose Weight }\end{array}$ \\
\hline & Neem & Neem & Azadirachta Indica & $\begin{array}{l}\text { Antibacterial Potential, Reduces Dandruff, Detoxifies the Body, } \\
\text { Treats Acne, Improves Gastric Health, Prevents Chronic } \\
\text { Diseases, Exfoliating Properties, Inhibits Fungal Infections, } \\
\text { Controls Diabetes, Treats Malaria, Improves Oral Health, } \\
\text { Reproductive Health, Anti-inflammatory Agent }\end{array}$ \\
\hline
\end{tabular}


Int.J.Curr.Microbiol.App.Sci (2018) 7(8): 4718-4726

Table. 2 Nutritional properties of powdered vegetables on the basis of through chemical analysis

\begin{tabular}{|l|c|c|c|c|c|c|c|c|c|c|c|}
\hline \multicolumn{1}{|c|}{ Parameters } & $\begin{array}{c}\text { Beet } \\
\text { root }\end{array}$ & $\begin{array}{c}\text { Bitter } \\
\text { gourd }\end{array}$ & $\begin{array}{c}\text { Rose } \\
\text { Patel }\end{array}$ & $\begin{array}{c}\text { Amla } \\
\text { raw }\end{array}$ & $\begin{array}{c}\text { Spinac } \\
\text { h raw }\end{array}$ & Carrot & Garlic & Quinao & $\begin{array}{c}\text { Drumsti } \\
\text { c leaf }\end{array}$ & $\begin{array}{c}\text { Neem } \\
\text { Curry } \\
\text { Patta }\end{array}$ \\
\hline Moisture \% & - & - & - & 6.29 & 5.23 & 7.64 & 4.34 & 5.06 & 5.06 & - & - \\
\hline Fat \% & - & - & - & 3.1 & 4.0 & 1.67 & 0.93 & 5.01 & 4.03 & - & - \\
\hline Protein \% & - & - & - & 3.48 & 27.79 & 7.59 & 12.11 & 13.42 & 20.88 & 13.23 & 10.17 \\
\hline Ash \% & - & - & - & 2.58 & 25.76 & 6.70 & 2.70 & 3.52 & 18.91 & - & - \\
\hline $\begin{array}{l}\text { Phosphorus } \\
\text { (mg/100g) }\end{array}$ & - & - & - & 87.65 & 291.00 & 254.92 & 328 & 312 & 378 & - & - \\
\hline Iron (mg/100g) & 5.64 & - & - & 22.90 & 93.19 & 24.18 & 19 & 23.00 & 87 & - & - \\
\hline Calcium \% & - & - & - & 0.068 & 0.108 & 0.074 & 0.128 & 0.053 & 0.5011 & - & - \\
\hline $\begin{array}{l}\text { Dietary Fibber } \\
\%\end{array}$ & - & 1.7 & - & 2.85 & - & - & - & - & - & - & - \\
\hline Vita C & - & - & 109.1 & 117.03 & - & - & - & - & - & - & - \\
\hline $\begin{array}{l}\text { Beta Carotene } \\
\text { ug/kg }\end{array}$ & 436.0 & - & - & - & - & 326.16 & - & - & - & - & - \\
\hline
\end{tabular}

Table.3 Therapeutic recognition of Nutraceuticals among different patients

\begin{tabular}{|c|l|c|c|c|}
\hline S. No. & \multicolumn{1}{|c|}{ Diseases } & No. of Patients & Frequency & Parcentage \\
\hline 1 & Renal & 5 & 4 & $80 \%$ \\
\hline 2 & Hepatic & 5 & 4 & $80 \%$ \\
\hline 3 & Diabetic & 5 & 5 & $100 \%$ \\
\hline 4 & Hair lose & 5 & 5 & $100 \%$ \\
\hline 5 & Joint Ailments & 5 & 5 & $100 \%$ \\
\hline 6 & Pulmonary diseases & 5 & 5 & $100 \%$ \\
\hline 7 & Cardiac Arrest & 5 & 3 & $60 \%$ \\
\hline
\end{tabular}

Table.4 Benefits of multigrain + vegetable Nutrient rich cookies on different age group of children \& women

\begin{tabular}{|c|l|c|c|}
\hline \multicolumn{1}{|c|}{ Groups } & F & Parcetage \\
\hline $\mathbf{1}$ & 3-6 years & 3 & $60 \%$ \\
\hline $\mathbf{2}$ & 6-10 years & 4 & $80 \%$ \\
\hline $\mathbf{3}$ & Adolescent girls & 5 & $100 \%$ \\
\hline $\mathbf{4}$ & Pregnant Women & 5 & $100 \%$ \\
\hline
\end{tabular}

Maximum contents of iron and phosphorus shows that these vegetables are good for strength and blood health. Quinoa is called as super food due to rich source of protein $(13.42 \%)$. Protein is also found in spinach $(27.79 \%)$ and Drumstick $(20.88 \%)$

Table 3 shows the therapeutic recognition among various patients it was observed that iron deficiency meet out using spinach, beetroot capsules. Hepatic patents were treated with chenopodium capsules and Diabetic and hair loss patients were treated with Methi, chenopodium and Amla capsules. Joint ailments and pulmonary problems were treated by Ashwagandha and Drumstick capsules. Quinnoa (A Super Food) since it is rich in protein $13.42 \%$, phosphorus, $312 \mathrm{mg}$ and iron $23 \mathrm{mg}$. It can be used in eradicating malnutrition. The rarely known and used 
drumstick leaves having protein composition $(20.88 \%)$, fat $(4.03 \%)$ and iron $(87 \mathrm{mg} / 100 \mathrm{~g})$ So it can be used as whole food supplement for person suffering from anaemia, bare diseases low in weight and breathing problems.

Table 4 shows the benefits of nutrient rich cookies of multigrain flour with sehjana powder, carrot powder, Beetroot powder, spinach and Chocolate powder on different age groups. It has been found that out of 5 kids of 3-6 yrs 3 kids (60\%) were benefitted. They liked choklet spinach vegetables cookies and consumed 4 to 6 cookies daily which resulted increase in haemoglobin level among them.

Children from 6-10 yrs age group 4 of them $(80 \%)$ were benefitted as they found themselves more energetic. Among adolescent girls all the 5 girls showed remarkable results as they were not found themselves week and dull. Their immunity and digestion power was increased. Pregnant women too showed good result that accounted for $100 \%$. They were completely free from fatigue and restlessness. Their digestion capacity was also increased.

It can be concluded from the above study that human life expiatory can be improved by the intake of medicinal herbs, spices and vegetables regularly which are nutrition's, control many health hazards and helps in maintaining good health. The herbs are the gift of nature and nutraceuticals are its processed form of intake which helps in improving health status. Therefore, it is recommended that intake of vegetables, spices and medicinal herbs, its powder and its nutraceuticals capsules can be beneficial for health due to their therapeutic characteristics as immunity developer, blood purifier, cholesterol controller, constipation remover, anti-allergic, anti-inflammatory, antibacterial and antifungal capacity.

In India we lack target oriented drug designing. Life-saving drugs work unidirectional i.e., they save vital organs but at the same time other vital organs face adverse effects. With use of these nutraceuticals one can be easily benefitted with good health and can prevent themselves from various diseases.

Prevention is the key we must take care of our diet so that we don't fall ill with use of these nutraceutical revolution will come in the field of food and nutrition and medical too, where all the allopathic drugs will be replaced by natural occurring capsules.

It is requirement of the hour to bring mental shift in the the thought process where we give much emphasis and value to surgeries and aloepathic medicines instead we must focus on balanced nutritious diet to avoid all the ailments and in the case of chronic diseases we must try to treat them naturally with natural herbs and vegetables. This way there will be more consumption i.e., more demand that will eventually lead to more production of fruits and vegetables. As a result farming community will be benefitted elevating their economic status and finances.

\section{References}

Adams, G.G. Imran, S., Wang, S., Mohammad, A., Kok, S., Gray, D.A., Channell, G.A., Morris, G.A. and Harding, S.E. (2011). The hypoglycaemic effect of pumpkins as anti-diabetic and functional medicines. Food Res. Internat., 44: 862-867.

Alamgir, M. and Uddin, S.J. (2010). Recent advances on the ethno medicinal plants as immunomodulatory agents. In: Ethno medicine: A Source of Complementary Therapeutics, Chattopadhyay, D. (Ed.). 
Research Signpost, Kerala, India, ISBN-13: 9788130803906, pp: 227244.

Azadbakht, L.F., Haghighatdoost, Karimi, G. and Esmaillazadeh, A. (2012). Effect of consuming salad and yogurt as preload on body weight management and cardivascular risk factors. A randomized clinical trial. Internat. $J$. Food Sci. Nutr., 10

Dahl, W.J., Foster, L.M. and Tyler, R.T. (2012). Review of the health benefits of peas (Pisum sativum L.). Br. J. Nutr., 108: S3-S10.

Ello-Martin, J.A., Ledikwe, J.H. and Rolls, B.J. (2005). The influence of food portion size and energy density on energy intake. Implications for weight management. Am. J. Clin. Nutr., 82: 236S-241S.

Esfahani, A., Wong, J.M.W., Truan, J., Villa, C.R., Mirrahimi, A., Srichaikul, K. and Kendall, C.W.C. (2011). Health effects of mixed fruit and vegetables concentrates: A systematic review of the clinical interventions. J. Am. Coll. Nutr., 30: 285-294.

Gibson, A., Edgar, A.D., Neville, C.E., Gilchrist, S.E. and Mckinley, M.C., Patterson, C.C., Young, I.S. and Woodside, J.V. (2012). Effect of fruit and vegetables consumption on immune function in older people: A randomized controlled trial. Am. J. Clin Nutr., 96: 1429-1436.

Hashemi, S.R. and Davoodi, H. (2012). Herbal plants as new immunostimulator in poultry industry. A review. Asian J. Anim. Vet. Adv., 7: 105-116.

Imai, S., Fukui, M., Ozasa, N., Ozeki, T., Kurokawa, M., Komatsu, T. and Kajiyama, S. (2012). Eating vegetables before carbohydrates improves postprandial glucose excursions. Diabetic Med., 30: 370-372.

Logendra, L.S., Gilrain, M.R., Gianfanga T.J. and Janes, H.W. (2002). Swiss chard: A salad crop for the space program. Life Support Biosph Sci., 8: 173-179.

Mathew, T.Z. Mathew and Dhama, K. (2010). Plants and herbs for the treatment of cancer in human and animals. Proceedings of the National Seminar on Advances in Animal Cancer Research in India: Diagnosis, Treatment and clinical management, June 15-16, 2010. Indian Veterinary Research Institute, Izatnagar (U.P.). India Souvenir, pp: 8586.

Mirzaei-Aghsaghali, A. (2012). Importance of medical herbs in animal feeding: A review. Ann. Biol. Res., 3: 918-923.

Park, S.H., Kyeong, M.S., Hwang, Y., Ryu, S.Y., Han, S.B. and Kim, Y. (2012). Inhibition of LPS binding to MD-2 coreceptor for suppressing TLR4mediated expression of inflammatory cytokine by 1-dehydro-10-gingerdione from dietary ginger. Biochem. Biophys. Res. Commun., 419: 735-740.

Stahl, W. and Sies, H. (2012). B-carotene and other carotenoids in protection from sunlight ${ }^{1,2,3}$. Am. J. Clin Nutr., 96: 1179S-1184S.

Sun, L., Zhu, H., Gan, L., Mo, J., Feng, F. and Zhou, C. (2012). [Constituents from the bark of Annona squamosa and their anti-tumor activity]. Zhongguo Zhong Yao Za Zhi, 37: 2100-2104.

Tan, B.K.H. and Vamitha, J. (2004). Immunomodulatory and antimicrobial effects of some traditional Chinese medicinal herbs. A review. Curr. Med. Chem., 11: 1423-1430.

Thangam, R., Suresh, V., Rajkumar, M., Vincent, J.D., Gunasekaran, P., Anbazhagan, C., Kaveri, K. and Kannan, S. (2013). Antioxidants and In vitro anticancer effect of 2pyrrolidinone rich fraction of Brassica oleracea var. capitata through induction of apoptosis in human cancer cells. 
Phytogether. Res., 27 (11): 1664-1670. Vazquez-Prieto, M.A. and Miatello, R.M. (2010). Organosulfur compounds and cardiovascular disease. Mol. Aspects Med., 31: 540-545

Wagensteen, H., Samuelsen, A.B. and Malterud, K.E. (2004). Antioxidants activity in extracts from coriander. Food Chem., 88: 293-297.

Wolfenden, R., Tellez, G., Pixley, C., Layton,
S. and Hargis, B. (2012). Probiotics/Direct Fed Microbials for Salmonella Control in Poultry. Food Res. Internat., 45 (2): 628-633.

Xiao, Z., Lester, G.E., Luo, Y. and Wang, Q. (2012). Assessment of vitamin and carotenoid concetrations of emerging food products. Edible microgreens. $J$. Agric. Food Chem., 60: 7644-7651.

\section{How to cite this article:}

Mamta Tiwari and Vijaya Tiwari. 2018. Therapeutic Recognition of Nutraceuticals for Health Benefits and Economic Uplifment of Farming Community. Int.J.Curr.Microbiol.App.Sci. 7(08): 4718-4726. doi: https://doi.org/10.20546/ijcmas.2018.708.496 